Ковалевська К.А.

Київький університет управління та підприємництва

\title{
СТРАТЕГІЧНІ ОРІЕНТИРИ ХОЛДИНГОВИХ КОМПАНІЙ МАШИНОБУДІВНОЇ ГАЛУЗІ УКРАЇНИ
}

\author{
СТРАТЕГИЧЕСКИЕ ОРИЕНТИРЫ ХОЛДИНГОВЫХ КОМПАНИЙ \\ МАШИНОСТРОИТЕЛЬНОЙ ОТРАСЛИ УКРАИНЫ
}

\section{STRATEGIC ORIENTS OF MACHINE-BUILDING HOLDING COMPANIES IN UKRAINE}

У статті досліджено соиіально-економічний стан машинобудівної галузі та зроблено висновок про необхідність технологічної і структурної перебудови виробництва на інновачійній основі. Розглянуто стратегічне управління холдинговими компаніями машинобудівної галузі на прикладах ПАТ «АвтоКраз», ПАТ «Луганськтепловоз» та ПАТ «Чорноморський суднобудівний завод». Визначено спільні стратегічні орієнтири розвиток компаній на інноваційній основі, використання корпоративних інформаційних технологій та розширення участі на міжнародному ринку. Поглиблено стратегічне управління холдинговими компаніями складовими активізації інноваційної діяльності інноваційною готовністю та спроможністю. Для підвищення інноваџійної готовності холдингу розширено функиіональні напрями системи управління - запропоновано концепцію управлінням узгодженням корпоративних інтересів суб'єктів корпоративних відносин. Розкрито дану концепцію через планування, організацію, мотивацію та контроль корпоративних інтересів акціонерів, топ-менеджерів та працівників.

Ключові слова: інноваційна спроможність, інноваційна готовність, корпоративні інтереси, управління узгодженням.

В статье исследовано социально-экономическое положение машиностроительной отрасли и сделан вывод о необходимости технологической и структурной перестройки производства на инновационной основе. Рассмотрено стратегическое управление холдинговыми компаниями машиностроительной отрасли на примерах ЧАО "АвтоКраз", ЧАО "Лугансктепловоз" и ЧАО "Черноморский судостроительный завод". Определено общие стратегические ориентиры - развитие компаний на инновачионной основе, использование корпоративных информачионных технологий и расширение участия на международном рынке. Углублено стратегическое управление холдинговыми компаниями составляюшими активизации инновационной деятельности - инноваџионной готовностью и способностью. Для повышения инноваџионной готовности холдинга расширено функииональные направления системы управления - предложено концепщию управлением согласованием корпоративными интересами субъектов корпоративных отношений. Раскрыто данную конщепцию через планирование, организаџию, мотивацию и контроль корпоративных интересов акиионеров, топ-менеджеров и работников.

Ключевые слова: инновационная способность, инновационная готовность, корпоративные интересы, управление согласованием. 
In the article the author investigated the socio-economic state of the machine-building industry and came to the conclusion about the necessity of technological and structural reorganizations of production on innovative basis. She examined strategic management of the machine-building holding companies PJSC "AvtoKraz ", PJSC "Luhanskteplovoz" and PJSC "Chornomorskyi sudnobudivnyi zavod". The author defined common strategic orients development of the companies on innovative basis, usage of corporate informational technologies and increasing the sales on the international market. She deepened strategic management by the components of innovation activity - innovative readiness and capacity. To increase innovative readiness of a holding company the author extended management functions - proposed the conception of management of corporate interests of the subjects of corporate relations. She presented this conception as planning, organization, motivation and control of corporate interests of shareholders, top-managers and workers.

Key words: innovative capacity, innovative readiness, corporate interests, harmonization of corporate interests.

Вступ. Посилення інтеграційних процесів з державами СНД та високо розвинутими країнами вимагає підвищення гнучкості промислового виробництва, що може бути здійснено за умови наявності достатнього інтелектуального та технологічного потенціалів компаній. Але складний соціально-економічний стан компаній, посилений фізичним та моральним старінням виробничих потужностей, знижує конкурентоспроможність вітчизняної продукції, потребує пошуку стратегічних напрямів ії покращення. Дане питання набуває особливої актуальності у контексті розвитку великого бізнесу, в якому провідна роль належить холдинговим компаніям. У науковій вітчизняній та зарубіжній літературі стратегічне управління компанією більшою мірою направлено на зміцнення інтересів власників бізнесу, проте інтересам інших суб'єктів корпоративних відносин - топ-менеджерів та працівників - приділено недостатньо уваги. Якщо інтереси топ-менеджерів задовольняються, про їх високі гонорари відомо спільноті, то інтереси працівників несправедливо ігноруються. А саме інтереси даної категорії повинні бути розглянуті в стратегічному розвитку компанії, оскільки дана більшість, володіючи суттєвим обсягом національного багатства країни, реалізує стратегічні цілі компаній та в цілому держави. В результаті вивчення джерел [1-4] було виявлено спроби розгляду корпоративних інтересів суб'єктів корпоративних відносин компаній, проте акцент на їх узгодженні на стратегічному рівні не наголошувався, що вимагає подальшого дослідження та пошуку напрямів вдосконалення.

Постановка завдання. Головною метою даного дослідження $\epsilon$ обгрунтування необхідності поглиблення стратегічного управління холдинговою компанією на засадах активізації інноваційної діяльності через узгодження інтересів суб'єктів корпоративних відносин.

Методологія. Теоретико-методологічну основу даного дослідження склали методи статистичного та порівняльного аналізу, теоретичного 
узагальнення, SWOT-аналізу, моделювання, а також системного підходу для вирішення проблем підвищення конкурентоспроможності холдингових компаній машинобудівної галузі.

Результати дослідження. Холдингові компанії машинобудування перебувають в умовах змінного оточуючого середовища, що спричинено нестабільним станом галузі. На це вказує тривала відсутність стабільно позитивної динаміки індексів виробництва машинобудівної продукції впродовж 2007 - 2013 рр (рис. 1). Основною причиною погіршення фінансово-економічного стану галузі стала світова фінансова криза, чиї наслідки компанії відчувають і дотепер. I незважаючи на зменшення коливань індексу цін та стабілізацію цінової політики (див. рис. 1), структура операційних витрат машинобудівної галузі вказує на складну ситуацію стосовно задоволення інтересів працівників у зв'язку з низьким приростом оплати праці.

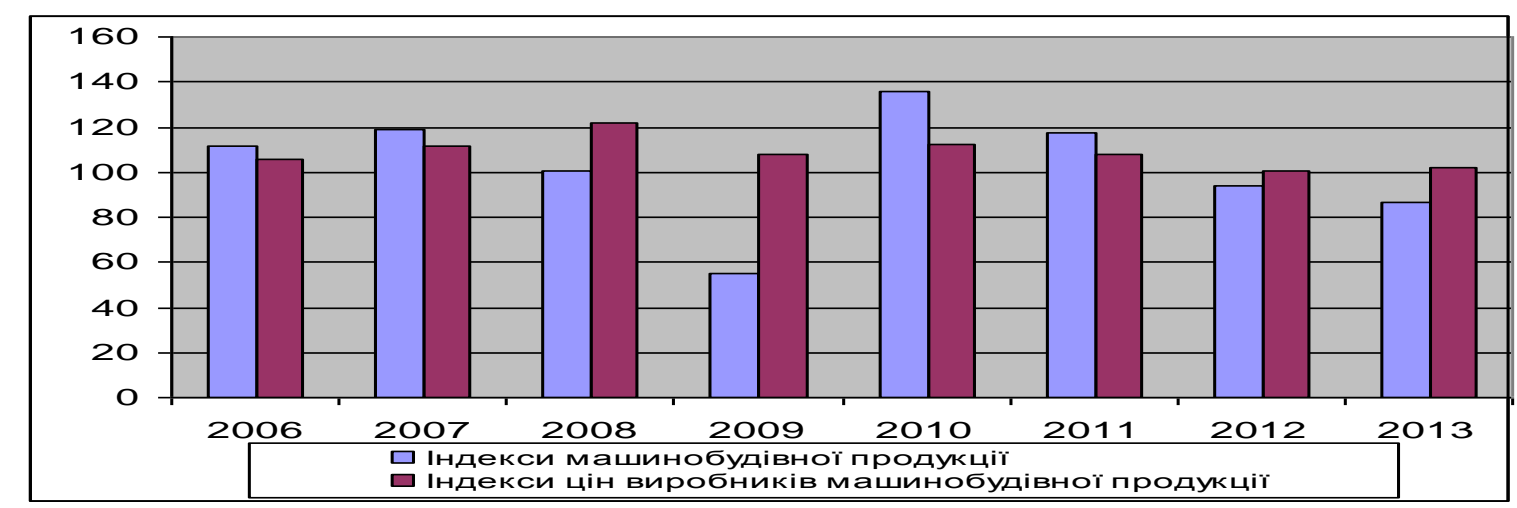

Рис. 1. Індекси виробництва та цін машинобудівної продукції [5]

Приріст оплати праці працівників у структурі операційного доходу 2011 році порівняно з 2007 роком склав 1,04 (табл. 1). Проте інтереси власників бізнесу у цьому періоді задовольнилися - приріст операційного прибутку склав 1,80 ( див. табл. 1).

Таблиця 1

Структура операційного доходу машинобудівної продукції, \% [5]

\begin{tabular}{|c|c|c|c|c|c|}
\hline Рік & $\begin{array}{c}\text { Матеріаль- } \\
\text { ні витрати }\end{array}$ & $\begin{array}{c}\text { Амортиза- } \\
\text { ція }\end{array}$ & Оплата праці & $\begin{array}{c}\text { Інші операційні } \\
\text { витрати }\end{array}$ & $\begin{array}{c}\text { Операційний } \\
\text { прибуток }\end{array}$ \\
\hline 2007 & 67,15 & 2,66 & 15,49 & 8,62 & 6,08 \\
\hline 2008 & 67,92 & 2,33 & 15,77 & 10,05 & 3,93 \\
\hline 2009 & 57,98 & 3,81 & 18,46 & 12,27 & 7,48 \\
\hline 2010 & 61,73 & 2,53 & 16,96 & 10,04 & 8,74 \\
\hline 2011 & 62,39 & 2,19 & 15,70 & 8,8 & 10,92 \\
\hline
\end{tabular}

Все це відбувалося на фоні активізації інноваційної діяльності промисловості та зростання кількості інноваційно-активних компаній у період 
2009-2012 pp, серед яких значну частку $(24,2-28,7$ \%) склали машинобудівні компанії (табл. 2).

Таблиця 2

Кількість інноваційно-активних підприємств, одиниць [5]

\begin{tabular}{|c|c|c|c|}
\hline Рік & Промисловість & Машинобудування & Питома вага, $\%$ \\
\hline 2007 & 1472 & 421 & 28,6 \\
\hline 2008 & 1397 & 400 & 28,6 \\
\hline 2009 & 1411 & 406 & 28,7 \\
\hline 2010 & 1462 & 417 & 28,5 \\
\hline 2011 & 1679 & 443 & 26,4 \\
\hline 2012 & 1758 & 426 & 24,2 \\
\hline 2013 & 1705 & 399 & 23,4 \\
\hline
\end{tabular}

Відомо, що машинобудування становить основу відтворювального процесу в національній економіці, тому пошук напрямів стимулювання інноваційної діяльності стає пріоритетним. Економісти одностайні у необхідності активного залучення висококваліфікованих та досвідчених працівників, відмічаючи також їхню потребу у достойній оплаті та умовах праці. Але насправді рівень оплати праці працівників даної галузі нижчий за середній показник промисловості, що підтверджується результатами порівняльного аналізу середньомісячної заробітної платні працівника машинобудування 3 оплатою праці добувної та переробної сфер промисловості (табл. 3).

Таблиця 3

Середньомісячна номінальна заробітна плата працівника, грн [5]

\begin{tabular}{|c|c|c|c|c|c|c|c|}
\hline Рік & $\begin{array}{c}\text { Промис- } \\
\text { ловість }\end{array}$ & $\begin{array}{c}\text { Добувна } \\
\text { промис- } \\
\text { ловість }\end{array}$ & $\begin{array}{c}\text { Переробна } \\
\text { промисло- } \\
\text { вість }\end{array}$ & $\begin{array}{c}\text { Машино- } \\
\text { будуванн } \\
\text { я }\end{array}$ & $\begin{array}{c}\text { Відх. 1 } \\
\text { гр. 5-гр. } \\
2)\end{array}$ & $\begin{array}{c}\text { Відх. 2 } \\
\text { гр. 5- } \\
\text { гр.3) }\end{array}$ & $\begin{array}{c}\text { Відх.3 } \\
\text { (гр. 5- } \\
\text { гр. 4) }\end{array}$ \\
\hline 1 & 2 & 3 & 4 & 5 & 6 & 7 & 8 \\
\hline 2007 & 1554 & 1970 & 1456 & 1389 & -165 & -581 & -67 \\
\hline 2008 & 2017 & 2681 & 1849 & 1789 & -228 & -892 & -60 \\
\hline 2010 & 2117 & 2894 & 1856 & 1709 & -408 & -1185 & -147 \\
\hline 2011 & 3120 & 4370 & 2759 & 2762 & -358 & -1608 & +3 \\
\hline 2012 & 3500 & 4881 & 3085 & 3086 & -414 & -1795 & -1 \\
\hline 2013 & 3763 & 5266 & 3305 & 3229 & -534 & -2037 & -76 \\
\hline
\end{tabular}

Така ситуація провокує соціальну напругу та поглиблює депресивний стан галузі, що визначений за результатами проведеного автором SWOTаналізу (рис. 2). Поділяючи думку авторів стосовно необхідності здійснення важливих кроків з боку держави та власників бізнесу у напрямі забезпечення стійкого розвитку галузі через технологічну i структурну перебудови 
виробництва на інвестиційно-інноваційній основі 3 метою подолання кризових фінансових явищ сьогодення [6], слід відзначити, що безпосередніми виконавцями цих завдань стають топ-менеджери та працівники компаній, чиї інтереси не завжди співпадають із загальнодержавними та загальнокорпоративними. Саме тому власникам слід ініціювати активне залучення працівників до інноваційного процесу, забезпечити контроль за його розвитком. У свою чергу перед топменеджерами стоїть завдання зі створення бази інноваційних знань, організації обміну досвідом між працівниками, створення умов для здійснення управління знаннями [10]. Цьому може посприяти ефективне співробітництво працівників із топ-менеджерами у єдиному стратегічному напряму, що задовольняє акціонерів. Одним із напрямів налагодження такого співробітництва може стати узгодження інтересів даних суб'єктів корпоративних відносин у стратегічному управлінні. А допоки стратегічне управління холдингів, що досліджено на прикладах ПАТ «АвтоКраз», ПАТ «Луганськтепловоз» та ПАТ «Чорноморський суднобудівний завод», недостатньо зорієнтовано на узгодження корпоративних інтересів суб'єктів корпоративних відносин.

Порівняння місій названих вище холдингів вказало на їхню однакову стратегічну направленість - задоволення потреб вітчизняних кліснтів та поступове розширення попиту на міжнародному ринку. Проте заявляючи про розширення ринків збуту, власники бізнесу розглядають місію як сенс існування компанії з позиції задоволення лише своїх власних потреб та потреб клієнтів. 


\begin{tabular}{|c|c|}
\hline Сильні сторони машинобудування & Слабкі сторони машинобудування \\
\hline $\begin{array}{l}\text { - наявність підприємств, що випускають } \\
\text { унікальну продукцію; } \\
\text { - наявність науково-дослідних інститутів } \\
\text { при виробництві; } \\
\text { - прагнення до побудови вертикально } \\
\text { інтегрованого ланцюга та бажання його } \\
\text { повністю замкнути }\end{array}$ & $\begin{array}{l}\text { - низька конкурентоспроможність продукції } \\
\text { та сервісного обслуговування; } \\
\text { - висока залежність від цін на сировину та } \\
\text { матеріали; } \\
\text { - низька мотивація та заробітна платня } \\
\text { працівників та, як наслідок, низька } \\
\text { продуктивність праці та поступове зниження } \\
\text { кваліфікації; } \\
\text { - низька інноваційна активність; } \\
\text { - низька інвестиційна привабливість через } \\
\text { тяжкий фінансовий стан та зношення } \\
\text { основних фондів; } \\
\text { - невідповідність управління сучасним } \\
\text { світовим вимогам }\end{array}$ \\
\hline Можливості оточуючого середовища & Загрози оточуючого середовища \\
\hline $\begin{array}{l}\text { - стабільний попит на ринку Росії та } \\
\text { інших країнах СНД; } \\
\text { - пожвавлення } \\
\text { національного ринку унурішнього } \\
\text { модернізацією та технічним оновленням } \\
\text { металургійної галузі; } \\
\text { - поліпшення інвестиційного клімату та } \\
\text { поява можливості залучення іноземного } \\
\text { капіталу } \\
\text { - посилення інтеграційних процесів та } \\
\text { можливість виходу компаній } \\
\text { глобальний ринок первинного розміщення } \\
\text { акцій }\end{array}$ & $\begin{array}{l}\text { - відсутність стабільного фінансування } \\
\text { галузі з боку державного бюджету; } \\
\text { - політизація холдингових компаній; } \\
\text { - світова фінансова криза; } \\
\text { - зростання цін на сировину; } \\
\text { - нестабільність курсів світових валют; } \\
\text { - висока конкуренція }\end{array}$ \\
\hline
\end{tabular}

Рис. 2. SWOT-аналіз машинобудівної галузі [складено автором]

Тривалий досвід ПАТ «Чорноморський суднобудівний завод» в суднобудуванні, унікальні технології, кваліфіковані кадри дозволяють компанії випускати продукцію на рівні світових стандартів. Враховуючи значну ступінь зносу основних засобів (табл. 4), холдинг дотримується стратегії відновлення та модернізації виробничих потужностей, реалізує інвестиційні програми, збільшує портфель заказів на будівництво суден, а також залучає додаткові замовлення на здійснення судоремонтних робіт.

Таблиця 4

Коефіцієнт зношеності основних засобів, \% [7 - 9]

\begin{tabular}{|l|c|c|c|c|c|c|c|}
\hline \multicolumn{1}{|c|}{ Компанія } & $\mathbf{2 0 0 7}$ & $\mathbf{2 0 0 8}$ & $\mathbf{2 0 0 9}$ & $\mathbf{2 0 1 0}$ & $\mathbf{2 0 1 1}$ & $\mathbf{2 0 1 2}$ & $\mathbf{2 0 1 3}$ \\
\hline АвтоКраз & 93,2 & 90,5 & 91,0 & 91,5 & 91,9 & 93,1 & 99,6 \\
\hline Луганськтепловоз & 65,8 & 66,2 & 66,6 & 67,9 & 70,6 & 14,4 & 22,6 \\
\hline $\begin{array}{l}\text { Чорноморський } \\
\text { суднобудівний } \\
\text { завод }\end{array}$ & 62,9 & 60,7 & 59,5 & 60,1 & 59,3 & 59,6 & 61,1 \\
\hline
\end{tabular}

До факторів, що послаблюють виконання стратегічних цілей, керівництво холдингової компанії відносить нестабільність законодавчої бази, високі податки, високі ціни на енергоносії та високу мінімальну заробітну платню [9]. Прикро, що керівництво вважає негативним явищем високу 
мінімальну заробітну платню, оскільки саме достойний рівень оплати праці, на наш погляд, дозволив компанії покращити результати фінансовоекономічної діяльності (табл. 5). Таке нехтування вкладу працівників у фінансово-економічні результати компанії неприпустиме та свідчить про наявність внутрішньо-комунікаційних бар'єрів. А віднесення інформації про стратегічні орієнтири та плани холдингу до комерційної таємниці вказує на бажання власників відгородитися від працівників та не залучати їх до управління. Це у майбутньому негативно відобразиться на конкурентоспроможності компанії. Але керівництво продовжує ігнорувати наявні труднощі, спрямовуючи значні зусилля та ресурси на відновлення та модернізацію потужностей задля збільшення ринку збуту, забуваючи що цей стратегічний напрям потребує залучення в управління досвідчених та кваліфікованих кадрів. Подібна стратегія погіршує і без того складний фінансових стан холдингу, що підсилюється підвищенням розміру позичкового капіталу та банківськими відсотками за кредитами.

На відміну від ПАТ «Чорноморський суднобудівний завод» холдингова компанія ПАТ «АвтоКраз» $\epsilon$ більш прозорою та офіційно оприлюднює стратегічні плани та результати свого SWOT-аналізу. Даний аналіз допоміг холдингу визначити такі проблеми [7]: значний знос основних фондів; недостатність висококваліфікованих кадрів; постійне зростання цін на матеріальні та енергетичні ресурси, що зменшує обігові кошти холдингу; нестабільна робота постачальників; законодавчі зміни в законодавстві Російської Федерації; наслідки світової фінансової кризи.

Таблиця 5

Корпоративні інтереси суб’єктів корпоративних відносин [7 - 9]

\begin{tabular}{|c|c|c|c|c|}
\hline \multirow{2}{*}{ Рік } & \multicolumn{2}{|c|}{ Акціонери } & \multicolumn{2}{|c|}{ Топ-менеджери та працівники } \\
\cline { 2 - 5 } & $\begin{array}{c}\text { Пистий } \\
\text { тис. грн }\end{array}$ & $\begin{array}{c}\text { Дивіден- } \\
\text { ди, тис. } \\
\text { грн }\end{array}$ & $\begin{array}{c}\text { Середньомісячна } \\
\text { заробітна платня } \\
\text { працівника холдингу, } \\
\text { тис. грн }\end{array}$ & $\begin{array}{c}\text { Середньомісячна заробітна } \\
\text { платня працівника галузі, } \\
\text { тис. грн }\end{array}$ \\
\hline \multicolumn{5}{|c|}{ ПАТ «АвтоКраз» } \\
\hline 2007 & 74229 & 0 & 1,881 & 1,389 \\
\hline 2008 & 66118 & 0 & 2,347 & 1,789 \\
\hline 2009 & 30942 & 0 & 1,257 & 2,709 \\
\hline 2010 & 10435 & 0 & 1,859 & 2,762 \\
\hline 2011 & -177142 & 0 & 2,391 & 3,086 \\
\hline 2012 & 15229 & 0 & 2,799 & 3,229 \\
\hline 2013 & 19578 & 0 & 2,979 & 1,389 \\
\hline & & \multicolumn{5}{|c|}{ ПАТ «Луганськтепловоз» } \\
\hline 2007 & -14754 & 0 & 1,701 & 1,789 \\
\hline 2008 & 1081 & 0 & 2,542 & \\
\hline
\end{tabular}




\begin{tabular}{|c|c|c|c|c|}
\hline 2009 & -157381 & 0 & 1,587 & 1,709 \\
\hline 2010 & -7457 & 0 & 2,596 & 2,262 \\
\hline 2011 & 71824 & 0 & 3,557 & 2,762 \\
\hline 2012 & 38724 & 0 & 5,110 & 3,086 \\
\hline 2013 & 158283 & 0 & 7,236 & 3,229 \\
\hline \multicolumn{5}{|c|}{ ПАТ «Чорноморський суднобудівний завод» } \\
\hline 2007 & -32821 & 0 & 1,867 & 1,389 \\
\hline 2008 & -40210 & 0 & 2,511 & 1,789 \\
\hline 2009 & 669 & 0 & 2,937 & 1,709 \\
\hline 2010 & 869 & 0 & 2,885 & 2,262 \\
\hline 2011 & 1235 & 0 & 3,737 & 2,762 \\
\hline 2012 & 602 & 0 & 4,269 & 3,086 \\
\hline 2013 & 207 & 0 & 4,340 & 3,229 \\
\hline
\end{tabular}

Для подолання означених вище негативних моментів холдинг розроблює i реалізує плани оптимального використання обладнання та технологічного переоснащення виробництва, реалізує інвестиційні плани технічного переозброєння $\mathrm{i}$ модернізації основних засобів та створює сучасний виробничий процес на основі енергозберігаючих технологій. Компанія здійснює пошук альтернативних постачальників та удосконалює логістику, здійснює розвиток маркетингової політики i мережі збуту на внутрішньому та міжнародних ринках. Глобальний стратегічний план ПАТ «АвтоКраз» передбачає нарощення обсягів виробництва i продажу автомобілів до шести тисяч одиниць на рік. Обрана холдингом стратегія виробництва спрямовує зусилля на підвищення рівня виробництва автотехніки, розвитку сервісної мережі та підвищення якості послуг до рівня закордонних компаній. У період 2005-2012 рр для технічного переозброєння виробництва та впровадження енергозберігаючих технологій підприємство витратило понад 130 млн.грн на придбання сучасного обладнання для агрегатного та складального виробництва [7]. Визнаючи недостатність кваліфікованих працівників у ПАТ «АвтоКраз» створено учбовий центр по підготовці кадрів дефіцитних професій. Але потрібно відзначити, що такі заходи лише частково та тимчасово вирішують проблему компанії, оскільки низька заробітна платня (див. табл. 5) спонукає працівників, отримавши необхідний досвід, шукати інші робочі місця. Отже, одночасно з розвитком власної навчальної бази холдингу потрібно піднімати рівень оплати працівників та вдосконалювати систему матеріального стимулювання, що повинна бути зорієнтована на стратегічний результат, погоджений із усіма учасниками корпоративних відносин. 
Зі схожими труднощами у подоланні негативних наслідків оточуючого та внутрішнього середовищ зіштовхнувся холдинг ПАТ «Луганськтепловоз». Холдинговою компанією розроблено «Перспективний план розвитку ПАТ «Луганськтепловоз» на 2008-2015 рр», що передбачає використання стратегії виробництва для розширення ринку збуту Російської Федерації [8]. Компанією визначено стратегічні цілі - забезпечення прибутковості діяльності, зростання обсягів виробництва продукції, підвищення якості продукції. До тактичних цілей віднесено: відновлення виробництва i реконструкція підприємства; збільшення навантаження виробничих потужностей, розширення випуску продукції на російському ринку. Для досягнення зазначених стратегічних цілей передбачено проведення таких заходів [8]: подолання наслідків фінансової кризи; визначення перспективної номенклатури продукції; нарощування обсягів виробництва; відновлення i подальший розвиток виробництва; вдосконалення конструкції виробів, що випускаються; проведення наукових досліджень і сертифікація за стандартом ISO9000 нових виробів; розвиток інформаційних технологій. Для подальшого освоєння ринків України i Росії прогнозовано проведення стратегії, спрямованої на зниження собівартості продукції, використання сучасних технологій виробництва.

Порівнюючи стратегічні плани ПАТ «АвтоКраз», ПАТ «Луганськтепловоз», ПАТ «Чорноморський суднобудівний завод», приходимо до висновку, що стратегії холдингів відповідають загальнодержавному стратегічному розвитку галузі. Це підтверджують обрані ними стратегічні орієнтири - розвиток компанії на інноваційній основі, використання корпоративних інформаційних технологій та розширення участі на міжнародному ринку. За таких умов перед холдинговими компаніями постає питання активізації інноваційної діяльності.

Необхідно відмітити, що передумовами активізації інноваційної діяльності виступають інноваційна спроможність та готовність компанії. Якщо холдинг може бути інноваційно спроможний, про що свідчитимуть наявність інтелектуальної власності, нових технологій, кваліфікованого персоналу та фінансово-економічної стабільності, то це не означає, що він готовий до активізації інноваційної діяльності. Інноваційна готовність холдингу передбачає зменшення протидії працівників корпоративних підприємств змінам в компанії, що в першу чергу досягається за умови узгодження корпоративних інтересів суб'єктів корпоративних відносин. Тому стратегічне управління пропонуємо поглибити на стадії визначення стратегічних орієнтирів через врахування складових активізації інноваційної діяльності корпоративних підприємств, що отримує таке схематичне представлення (рис. 3). 


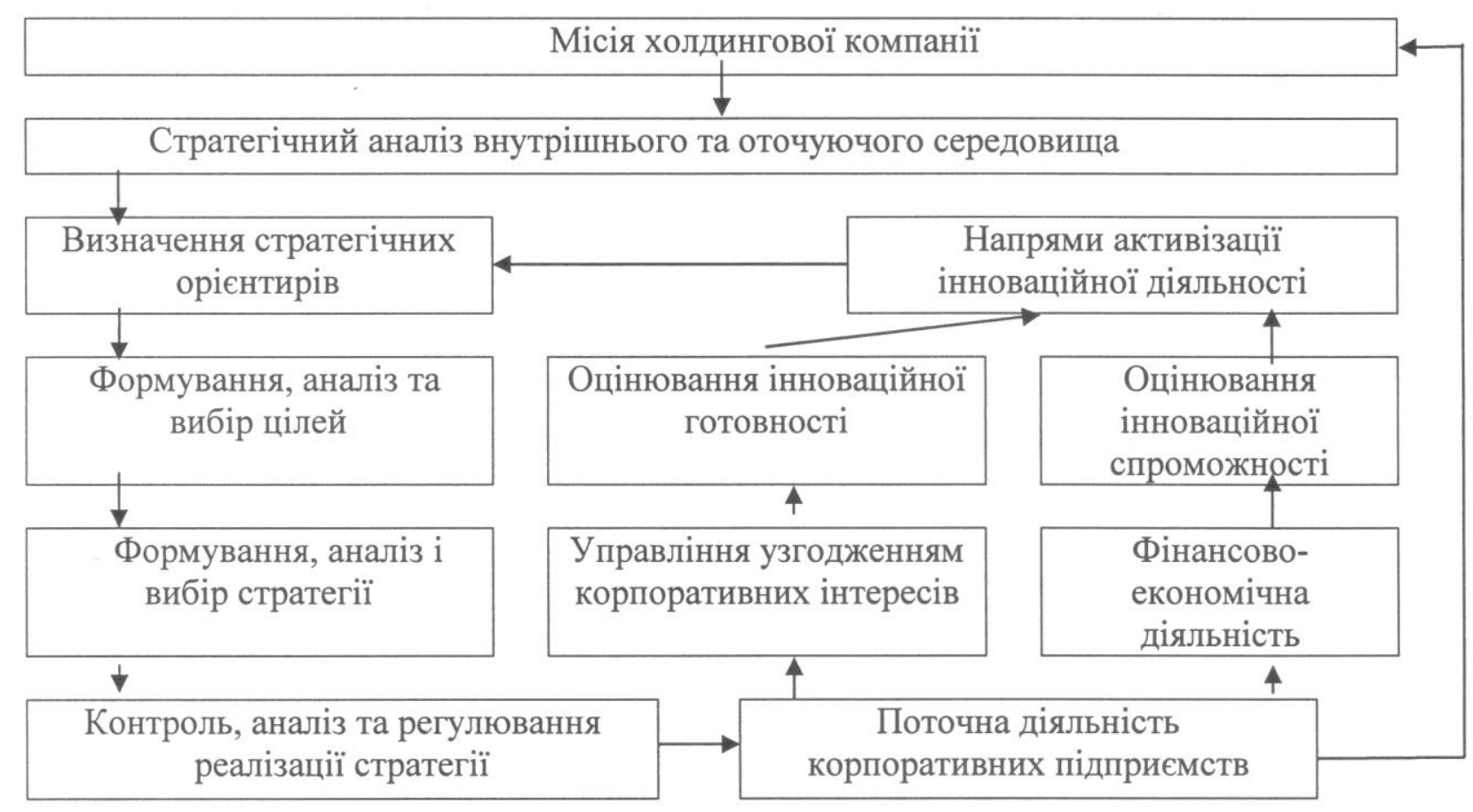

Рис. 3. Стратегічне управління холдингом [вдосконалено автором]

Не зупиняючись детально на методичних підходах щодо оцінювання інноваційної готовності та спроможності, розглянемо управління узгодженням корпоративних інтересів суб'єктів корпоративних відносин, що безпосередньо впливають на реалізацію задач стратегічного управління акціонерів, топ-менеджерів та працівників. У такому разі управління узгодженням корпоративних інтересів розглянуто як цілеспрямований вплив топ-менеджерів на корпоративні інтереси працівників для досягнення своїх власних інтересів та корпоративних інтересів акціонерів. Даний напрям системи управління холдингової компанії потребує виконання таких загальновідомих функцій як планування, організація, мотивація та контроль.

1. Планування - складова управління узгодженням корпоративних інтересів, що полягає у розробці плану узгодження та його реалізацію. План узгодження кількісно визначає розмір корпоративних інтересів суб'єктів корпоративних відносин корпоративних підприємств та управлінської компанії на наступний період. Наприклад, корпоративні інтереси акціонерів можуть бути кількісно виражені показником розміру виплати дивідендів, топменеджерів та працівників - достойними оплатою та умовами праці. Якщо розглянути під узгодженням корпоративних інтересів стратегічне планування обсягу реалізованої продукції, виходячи з можливостей виробництва та ринку збуту, та зорієнтувати управління на підвищення економічної доданої вартості, то перелік показників корпоративних інтересів можемо розширити такими показниками:

- акціонери (економічна додана вартість, показники прибутковості); 
- топ-менеджери (економічна додана вартість, показники прибутковості, обсяг реалізованої та товарної продукції);

- працівники (обсяг товарної продукції).

Реалізація плану узгодження передбачає обговорення та затвердження на загальних зборах акціонерів холдингової компанії переліку відповідальних осіб, розробку етапів виконання та шляхів досягнення.

2. Організація - сукупність принципів, форм та методів координації дій суб'єктів корпоративних відносин 3 метою досягнення узгодження їхніх корпоративних інтересів. Дана складова управління потребує налагодження внутрішньокорпоративних відносин та демократизації управління.

3. Мотивація - складова управління узгодженням корпоративних інтересів, що спонукає топ-менеджерів та працівників до діяльності для задоволення корпоративних інтересів акціонерів.

4. Контроль - оперативний процес пошуку причин відхилення досягнутих показників корпоративних інтересів від запланованих. Методологічною основою може слугувати контролінг.

Розглянуті функції дозволять забезпечити управління узгодженням корпоративних інтересів суб'єктів корпоративних відносин та сприятимуть створенню корпоративної культури холдингової компанії.

Висновки. Сучасний стан розвитку машинобудівної галузі вимагає від власників рішучих дій стосовно підвищення конкурентоспроможності компаній, що в умовах ринкових перетворень може бути досягнуто за умови активізації їхньої інноваційної діяльності. Проте діагностика соціальноекономічного становища галузі свідчить про низьку інноваційну спроможність машинобудівних компаній. Низька мотивація та заробітна плата працівників, небажання власників виконувати в повному обсязі свої інноваційні функції та внаслідок цього нести додаткові витрати ускладнює взаємовідносини не тільки між державою та акціонерами, а й між працівниками та топ-менеджерами. Дослідження стратегічних напрямів ПАТ «АвтоКраз», ПАТ «Луганськтепловоз» та ПАТ «Чорноморський суднобудівний завод» визначило їхню інноваційну спрямованість 3 одночасним неприйняттям людського капіталу як найважливішого елемента економіки та необхідності в його розкритті, фінансуванні для забезпечення інноваційного розвитку в довгостроковій перспективі. У зв'язку з чим запропоновано поглибити стратегічне управління складовими активізації інноваційної діяльності - інноваційною спроможністю та інноваційною готовністю, що реалізується в управлінні узгодженням корпоративних інтересів суб'єктів корпоративних відносин.

Науковою новизною дослідження $є$ вдосконалення теоретикометодичних основ стратегічного управління холдинговою компанією машинобудівної галузі, що поглиблено складовими активізації інноваційної 
діяльності на засадах управління узгодженням корпоративних інтересів суб'єктів корпоративних відносин.

Теоретичне та практичне значення результатів дослідження полягає в тому, що за результатами проведеного дослідження запропоновано додатковий напрям управління холдинговою компанією машинобудівної галузі - управління узгодженням корпоративних інтересів, що сприятиме підвищенню інноваційної готовності корпоративних підприємств. Отриманий теоретичний доробок може бути корисним підгрунтям для подальших теоретичних та практичних досліджень 3 даного напрямку.

Перспективи подальших наукових розробок за даним напрямом. Необхідно провести поглиблене дослідження зарубіжного досвіду щодо управління узгодженням корпоративних інтересів суб'єктів корпоративних відносин та напрямів реалізації у стратегічному управлінні холдингових компаній.

\section{Лiтература:}

1. Вартісно-орієнтований організаційно-економічний механізм корпоративного управління холдинговими компаніями: стратегія отримання комбінаторних переваг: монографія // Т. В. Момот, М. В. Кадничанський, О. А. Лобанов, Н. В. Рудь. - Х.: Фактор, 2010. $-220 \mathrm{c}$.

2. Гапоненко А.Л. Стратегическое управление: ученик / А.Л. Гапоненко, А.П. Панкрухин. - М. : Омега-Л, 2010. -472 с.

3. Методи фінансового та інвестиційного аналізу промислових підприємств: аналіт. огляд / [В.Я. Нусінов, В.М. Кутовий, Я.В. Нусінова та ін.] - Кривий Ріг : Вид. дім, 2006. $300 \mathrm{c}$.

4. Пріоритети інвестиційної політики у контексті модернізації економіки України / [Павлюк А.П., Покришка Д.С., Белінська Я.В. та ін.]. - К.: НІСД, 2013. - 48 с.

5. Статистичний щорічник України за 2012 рік. - К. : Консультант, 2010. - 551 с.

6. Перетятько А.В. Машинобудівний комплекс: проблеми управління стабільністю та шляхи їх вирішення [електронний ресурс] / А.В. Перетятько, Г.К. Яловий. - Режим доступу: http://www.economy.kpi.ua/

7. Офіційний сайт компанії «ХК «АвтоКраз» [Електронний ресурс]. - Режим доступу: http://www.autokraz.com.ua/

8. Офіційний сайт компанії ПАТ «Луганськтепловоз» [Електронний ресурс]. Режим доступу: http:// www.luganskteplovoz.bg.ua/

9. Офіційний сайт компанії ПАТ «Чорноморський суднобудівний завод» [Електронний ресурс]. - Режим доступу: http://chornomorskiy-sudnobudivniy-zavod.bg.ua

10. Huei Tse Hou New research on knowledge management models and methods [Electronic resource] / Huei Tse Hou. - available at: http://www.intechopen.com 